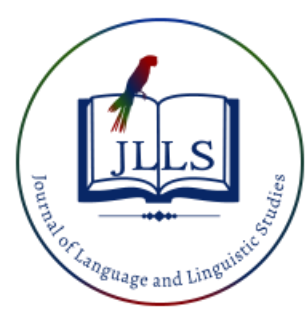

Available online at www.jlls.org

JOURNAL OF LANGUAGE AND LINGUISTIC STUDIES

ISSN: $1305-578 \mathrm{X}$

Journal of Language and Linguistic Studies, 16(3), 1458-1479; 2020

\title{
Tales for teaching German: Examining student-centered activities in terms of students' willingness to participate in the classroom
}

\author{
Nurcihan Sönmez Genç a 1 iD \\ ${ }^{a}$ Hacettepe University, Ankara, Turkey

\section{APA Citation:} \\ Sönmez-Genç, N. (2020). Tales for teaching German: Examining student-centered activities in terms of students' willingness to participate in \\ the classroom. Journal of Language and Linguistic Studies, 16(3), 1458-1479. \\ Submission Date:04/06/2020 \\ Acceptance Date:07/08/2020
}

\begin{abstract}
The goal of this study is to determine the willingness for participation and opinions of the high school students who learn German as a foreign language in the context of the student-centered activities carried out within the scope of a student-centered teaching approach lasting four weeks. The sample of the study consists of 20 students who continue their 11th grade education in a secondary school in Çankaya, Ankara in the spring term of the 20192020 academic year. The research was conducted with a mixed research method. As data collection tools, a questionnaire was used to determine the effect of student-centered activities on students' active willingness for course participation and a course evaluation form was used to determine students' opinions and views on the applied activities. Descriptive statistics were used in the analysis of quantitative data obtained from the questionnaire and course evaluation forms, and inductive content analysis was utilized in the analysis of qualitative data. As a consequence of the evaluation, it has been detected that student-centered activities, in which visual materials and creative work styles are used, contribute to the increase of the students' willingness to participate. Furthermore, it has been observed that these students shared the view that such activities were effective and useful for foreign language learning processes.
\end{abstract}

(C) 2020 JLLS and the Authors - Published by JLLS.

Keywords: foreign language teaching; German as a foreign language; student-centered teaching; student-centered activities; active participation in class

\section{Introduction}

In Turkey the importance of foreign language and foreign language education gradually increases day by day. Based on this understanding of education, the Ministry of National Education declared the 2023 Education Vision Document in order to overcome the shortcomings of the Turkish education system and to achieve a modern structure. This document demonstrates that the improvement and development of foreign language education are among the main targets of the Ministry of Education. Various goals were set in this document in order to realize the concrete steps which are planned to be taken in today's foreign language education. Within the scope of the first goal, it is emphasized that

\footnotetext{
${ }^{1}$ Corresponding author. Tel.: +90-312-297-8575

E-mail address: nurcihan.sonmez@hacettepe.edu.tr
} 
foreign language education should be carried out with a student-centered approach and using methods appropriate to the cognitive levels of the students (MEB, 2018, p. 65). Nevertheless, when foreign language teaching is examined within the scope of this goal, it can be observed that traditional language teaching habits have been applied on for a long time and the insufficiency of the methods, activities and material or mistakes caused by them prevent the students from being reached effectively (Can \& Can, 2014; Demirpolat, 2015; Güçlü \& Şahan, 2019; İşigüzel \& Kırmızı, 2013; Işık, 2009; Kırmızı, 2009; Küçüktepe, Eminoğlu Küçüktepe \& Baykın, 2014; Schröder, 2007). However, in contemporary foreign language education, with the acceptance that language learning is the process of constructing knowledge, making new meanings and not receiving the information presented, the view that teaching is conveying information has been abandoned (Açıkgöz, 2003, p. 57). Based on the principle of "learning by doing" (Kast, 1994) that is adopted as a result of the contributions of cognitive psychology to language education, it is known that student-centered foreign language course models, in which students can increase their performance by using their basic language skills, positively affect the learning process. For this reason, empirical language education researches based on academia and high school education cooperation for student-centered teaching practices and activities are of great importance (Ünal, 2005, p. 211).

Given this need, in this study, within the scope of application of German courses at the high school level in Turkey, it is attempted to determine how student-centered activities based on a fairy-tale text affect students' willingness for participation together with its reasons and suggestions for more effective teaching of German have been presented in line with the findings of the study.

\subsection{Literature review}

Student-centered methods and activities form a new paradigm in today's foreign language education. The traditional education approach and its applications such as not being able to provide permanent and participatory learning sufficiently, making the educational environments extremely static and formal, making the student passive, being based on memorization and predominantly on only lecturing, had an impact on the development of the student-centered education approach (Özpalat, 2013, p.8). The student-centered teaching approach, which is developed based on the constructivist learning theory, depends upon the student's being active in the learning process as opposed to the teacher-centered traditional foreign language education approach in which students are passive listeners (PortmanTselikas, 2010, p. 1167; Ünal, 2010, p. 63). It is essential to make use of various activities aiming at the active participation of students at the highest level in student-centered teaching models. These activities can also be termed as student-centered, product-oriented or action-oriented activities in the literature (Riemer, 2010, p.1154; Wicke, 2017, p. 5). Portman-Tselikas (2010, p. 1168) emphasizes that such activities are decisive for the effective and efficient implementation of the foreign language course and summarizes the five fundamental characteristics that such activities should have: Activities used in student-centered foreign language teaching a) should be compatible or integrable with the subjects and objectives of the foreign language curriculum that is applied; b) should provide an action and productoriented learning environment that offers students the goals that they can achieve; c) should allow students to organize and to direct their study processes within the framework of the instructions given; d) should include activities in which students concentrate on a subject using the foreign language intended to be learned and activities which provide communication opportunities or lead to communication in the foreign language in the classroom; e) should create interesting and remarkable learning moments aimed at the receptive or productive use of the foreign language in line with the objectives of the course.

When the studies about the participation of students in the activities offered within the scope of the student-centered courses are examined, it is observed that participation and motivation topics are 
intertwined and the active participation of the students in the learning process is significantly and positively associated with academic success, interest levels, attitudes and self-efficacy beliefs (Açıkgöz, 2003; Çanlığlu, 2014; Fink, 2003; Dockhorn, 2008; Duman \& Eren, 2014; İnci, 2019; Reeve \& Tseng, 2011; Schmidt, 2003; Üstün, 2016; Türk, 2012; Wicke, 2017). Reschly and Christenson (2006) define the willingness to participate as the link between activity and person, and motivation as energy in behavior. Gardner (1985, p. 50) describes participation willingness as "a goal, effortful behavior, a desire to attain the goal and favorable attitudes toward the activity in question". Therefore, the presence or absence of students' willingness for participate in an activity, in other words, the degree of their willingness to participate, also expresses their motivation level for participation in the course (Aypay \& Eryılmaz, 2011, p. 27).

The educators who adopt the student-centered education approach emphasize that in the development of language skills of foreign language learners, especially short lyrical and epic literary texts (such as fairy tales, short stories, poems, fables and song texts) should be utilized (Ehlers, 2010; Krauß, 2004; Hofmann, 2004; Ünal, 2018; Wicke, 2014). In this sense, the arguments of educators who favor benefiting from use of literature in foreign language education generally focus on the following lines: The fact that literature has a dialogue with the reader, thanks to the effect it has on the human with its fictionalism and unique structure, prepares the ground for the natural communication environment that the foreign language courses aim to achieve (Ünal, 2005, p. 204). Accordingly, educators have worked intensively on student-centered course models in which foreign language students can use and improve all language skills and they developed a three-stage teaching model (Caspari, 1997, p. 44; Nünning \& Surkamp, 2006, p. 77; Ünal, 2010, p. 64; Wicke, 2014, p. 5; Yılmaz \& Dilidüzgün, 2019, p. 225). The teaching model applied in order to activate the student in a foreign language course with literary texts was designed as three stages as pre-text, during text and post-text activities. The objectives of the three stages of the teaching model in question can be summarized as follows:

1. Stage - The objectives of student-centered activities before reading the text are:

- Enabling students to get acquainted with the subject to be covered by engaging their prior knowledge and arousing their curiosity;

- Activating related words and phrases;

2. Stage - The objectives of student-centered activities during the reading of the text are:

- Making students comprehend the text in a playful and enjoyable environment;

- Making students realize how language is used in communication;

3. Stage - The objectives of student-centered activities after reading the text are:

- Enabling students to realize creative speech and writing styles in a foreign language through their own works.

\subsection{Research questions}

The aim of this study is to determine the willingness of the students for the student-centered activities of the student-centered teaching model applied in the German courses at an Anatolian high school in Çankaya, Ankara, together with the reasons why students want to participate in the course. For this purpose, answers were sought for the following sub-problems:

1. What is the students' willingness to perform student-centered activities implemented in German lessons?

2. What are the views of students regarding their willingness to participate in student-centered activities implemented in German lessons?

3. What are the opinions of the students in general regarding the teaching of German lessons through student-centered activities? 


\section{Method}

In this study, where a mixed pattern was applied, quantitative data were obtained through student questionnaires and qualitative data were obtained through semi-structured course evaluation forms consisting of open-ended questions. The mixed research method adopted is defined as a research approach that integrates the two data sets and draws conclusions by using the advantages of integrating these two data sets in order to better understand the research problem and to examine the effect of student-centered activities on their willingness to participate in the course (Knorr \& Schramm, 2016, p. 92).

Within the scope of the study, the "Frog Prince" ("Froschkönig" in German) fairy tale text of the Brothers Grimm was selected and 15 student-centered activities were developed based on the threestage literature teaching model used in student-centered foreign language teaching. Student-centered activities developed according to the stages of the model in question are shown in Table 1 below.

Table 1. Student-centered activities implemented within the scope of the study.

\begin{tabular}{lll}
\hline \multicolumn{1}{c}{ Teaching phase } & \multicolumn{1}{c}{ Name of the activity } & \multicolumn{1}{c}{ Content of the activity } \\
\hline Before reading & 1. Puzzle & $\begin{array}{l}\text { Students work in pairs on puzzles consisting of images } \\
\text { of fairy tales to be taught. } \\
\text { 2. Matching Concepts }\end{array}$ \\
3. Analyzing the Title & $\begin{array}{l}\text { Students match the pictures hanging on the board and } \\
\text { the cards containing the key concepts. } \\
\text { Students produce ideas about the fairy tale title hanging } \\
\text { on the board. }\end{array}$
\end{tabular}

During reading $\quad$ 4. Listening (I)

5. Listening (II)

6. Listening (III)

7. Image-Text Matching

8. Defining Words

9. Finding a Title

10. Making fairy tale characters speak

11. Thought Balloons

12. Crossword
Students try to understand the subject of the tale in general by listening to the beginning of the tale,

Students try to find answers to the questions "Who?", "Where?", "When?", "What is going on?" by listening to the beginning of the tale again.

Students listen to the entire tale and number the pictures on the handouts in order.

Students match the parts of the text with the pictures hanging on the board in the correct order.

The students read the word descriptions on the handout and write down the word described.

Students try to find a title for the visuals of the fairy tale on the handout.

Students write short dialogues for the fairy-tale character in the pictures on the handout.

Students match the thought balloons that are mixed up on the board with the fairy tale characters they belong to.

Students solve a crossword puzzle asking questions about the fairy-tale. 


\begin{tabular}{lll}
\hline After reading & 13. Role Playing & $\begin{array}{l}\text { Students play role by reading role cards of fairy-tale } \\
\text { characters and using role masks. }\end{array}$ \\
14. Writing a Poem & $\begin{array}{l}\text { Students write a poem using fairy-tale words and } \\
\text { expressions. }\end{array}$ \\
15. Poetry Collage & $\begin{array}{l}\text { The students prepare the collages of the poems they } \\
\text { created before with the colored pictures, fairy tale text, } \\
\text { colored pencils and cardboards given. }\end{array}$
\end{tabular}

The activities developed and the scales to be used in this context were applied to the 11th grade students of a secondary school in Çankaya, Ankara. Through a questionnaire, the students were asked to express their desire to perform the activities that were implemented in the relevant week after the course applications. In order to support the quantitative data obtained within the scope of the study with qualitative data and to reach the students' opinions which are not covered by the questionnaire, the students who completed the questionnaire were asked to fill out a course evaluation form in order for them to interpret their participation willingness they stated within the scope of the questionnaire application.

\subsection{Participants}

The research sample selected by random method among the students who continue their 11th grade education and learn German as a second foreign language in a secondary school in Çankaya, Ankara in the spring term of the 2019-2020 academic year consists of $80 \%(n=16)$ female and $20 \%(n=4)$ male students. The average age of the students participating in the study is between 17-18 years old. The course practices applied were carried out within the scope of German lessons for four weeks and two hours a week with the participation of the students in the sample mentioned above.

Participation rates, gender and age information of students forming the sample are presented in Table 2.

Table 2. Demographic Information of the Participants.

\begin{tabular}{|c|c|c|c|c|}
\hline Course Application & Variable & & $\mathrm{N}$ & $\%$ \\
\hline \multirow{6}{*}{ 1. Course Application } & \multirow{3}{*}{ Gender } & Female & 16 & 80 \\
\hline & & Male & 4 & 20 \\
\hline & & Total & 20 & 100 \\
\hline & \multirow{3}{*}{ Age } & 17 & 19 & 95 \\
\hline & & 18 & 1 & 5 \\
\hline & & Total & 20 & 100 \\
\hline \multirow{6}{*}{ 2. Course Application } & \multirow{3}{*}{ Gender } & Female & 13 & 86,67 \\
\hline & & Male & 2 & 13,33 \\
\hline & & Total & 15 & 100 \\
\hline & \multirow{3}{*}{ Age } & 17 & 14 & 93,33 \\
\hline & & 18 & 1 & 6,67 \\
\hline & & Total & 15 & 100 \\
\hline \multirow{5}{*}{ 3. Course Application } & \multirow{3}{*}{ Gender } & Female & 12 & 80 \\
\hline & & Male & 3 & 20 \\
\hline & & Total & 15 & 100 \\
\hline & \multirow[t]{2}{*}{ Age } & 17 & 14 & 93,33 \\
\hline & & 18 & 1 & 6,67 \\
\hline
\end{tabular}




\begin{tabular}{|c|c|c|c|c|}
\hline & & & & \\
\hline & & Total & 15 & 100 \\
\hline \multirow{6}{*}{ 4. Course Application } & \multirow{3}{*}{ Gender } & Female & 8 & 72,73 \\
\hline & & Male & 3 & 27,27 \\
\hline & & Total & 11 & 100 \\
\hline & \multirow{3}{*}{ Age } & 17 & 10 & 93,33 \\
\hline & & 18 & 1 & 6,67 \\
\hline & & Total & 11 & 100 \\
\hline
\end{tabular}

As seen in Table 2, 20 students participated in the first course application, 16 of whom were female and 4 were male. 15 students belonging to the sample of 20 participated in the second course application, 13 of whom were female and 2 were male 15 students participated in the third course application, 12 of whom were female and 3 were male. A total of 11 students participated in the fourth course application, 8 of whom were female and 3 were male.

\subsection{Instrument( $s)$}

In the study, a questionnaire was used to determine the effect of the student-centered activities on the students' participation willingness and a course evaluation form was used to determine the opinions and views of the students about the applied activities. The Questionnaire and Evaluation Form were developed by the researcher with the support of a faculty member specialized in research methods in foreign language education.

The questionnaire, which aims to identify the high school students' wishes to fulfill 15 studentcentered activities implemented within the German lesson, has been prepared in two parts. In the first part of the questionnaire, information is provided to obtain data on students' socio-demographic characteristics (i.e. age, gender, class and section). The second part of the questionnaire consists of 15 items with a seven-point Likert-type answer scale. After reading the statement describing the activity applied within the scope of the course, the students were asked to mark the most appropriate one in answer categories ranging from "none" to "very high". In the scoring of the items, "none" gets 1 and "very high" gets 7 points; the high score indicates that the willingness to fulfill that activity is higher. In addition, after marking the request for participation, the students were asked to explain the reason for the marking in one or two sentences. In addition, students who completed the questionnaire were asked to fill out a semi-structured course evaluation form consisting of open-ended questions. The course evaluation form includes 8 open-ended questions (e.g. "What did I do in the course this week?"; "What did I learn in the course this week?"; "What advice do I have for this week's course?"). The average time for students to complete the questionnaire and course evaluation form was 20 minutes.

\subsection{Data collection and analysis}

The student-centered activities developed within the scope of the study were implemented by a faculty member for a total of eight hours for four weeks and two hours a week, on students attending 11th grade education of a secondary school in Çankaya, Ankara. After the mentioned course applications were carried out, the students were asked to state their willingness to perform the activities implemented in the relevant week through a questionnaire and to express their thoughts and opinions about each activity and education by completing a course evaluation form. The questionnaires and course evaluation forms filled by the students were transferred to Microsoft Word and Excel programs as raw data without any elimination in order to perform computer-aided data analysis. MAXQDA-data analysis software (Version 20.0.7) was used for the analysis of qualitative data obtained from the course evaluation forms, 
and MAXQDA Stats-statistics module belonging to the MAXQDA-data analysis software was used for the analysis of quantitative data obtained from surveys and text studies.

Quantitative data obtained from the questionnaires applied to determine the effect of student-centered activities on students' willingness to participate were analyzed with MAXQDA Stats - Statistics Program and arithmetic means and standard deviations of the data were calculated. In addition, Cronbach's alpha reliability coefficient of the scale was found to calculate the reliability of the survey used and this coefficient was interpreted according to the classification made by Baş (2005). Cronbach's alpha reliability coefficient of the scale used was found 0.73 . This reliability coefficient showed that the scale used was quite reliable.

Inductive content analysis format was used to analyze the raw data in the course evaluation forms, and thematic codings were classified into certain categories and sub-categories. With the coding made, it was aimed to "reveal the underlying concepts of the data and the relationships between these concepts" (Yıldırım \& Şimşek, 2005, p. 227). In this context, four analysis stages (coding data, finding themes, editing codes and themes, and identifying and interpreting the findings) were applied in the processing of qualitative research data (Burwitz-Melzer \& Steiniger, 2016, p. 259; Güler, Halıcıoğlu \& Taşgın, 2015, p. 331; Yıldırım \& Şimşek, 2005, p. 228). Themes and sub-themes, selected and organized within the scope of the research, are presented in the conclusion section, with specific inferences that reflect frequency numbers and their meaning in the most appropriate way.

\section{Results}

The results obtained from the scales used to determine the willingness for participation and opinions of the high school students who learn German as a foreign language in context of the student-centered activities are presented below.

\subsection{Students' Willingness to Perform Student-Centered Activities}

As a result of the statistical analysis of the data obtained from the student surveys in the study, the findings reflecting the students' willingness to perform student-centered activities are presented in Table 3.

Table 3. Willingness to Perform Student-Centered Activities

\begin{tabular}{|c|c|c|c|c|c|c|c|c|c|c|c|c|}
\hline \multirow[b]{2}{*}{ N. } & \multirow[b]{2}{*}{ Activities } & \multirow[b]{2}{*}{$\mathbf{N}$} & \multirow{2}{*}{$\begin{array}{l}\mathbf{f} \\
/ \\
\%\end{array}$} & \multicolumn{7}{|c|}{ Likert } & \multirow[b]{2}{*}{$\mathbf{M}$} & \multirow[b]{2}{*}{ SD } \\
\hline & & & & 1 & 2 & 3 & 4 & 5 & 6 & 7 & & \\
\hline \multirow[t]{2}{*}{1} & \multirow{2}{*}{$\begin{array}{l}\text { Making fairy tale characters } \\
\text { speak }\end{array}$} & \multirow{2}{*}{15} & $\mathrm{f}$ & - & 1 & 2 & - & 3 & 1 & 8 & \multirow{2}{*}{5,67} & \multirow{2}{*}{1,70} \\
\hline & & & $\%$ & - & 6,67 & 13,33 & - & 20,00 & 6,67 & 53,33 & & \\
\hline \multirow[t]{2}{*}{2} & \multirow[t]{2}{*}{ Poetry collage } & \multirow{2}{*}{11} & f & - & - & - & 2 & 3 & 4 & 2 & \multirow{2}{*}{5,55} & \multirow{2}{*}{0,98} \\
\hline & & & $\%$ & - & - & - & 18,18 & 27,27 & 36,36 & 18,18 & & \\
\hline \multirow[t]{2}{*}{3} & \multirow[t]{2}{*}{ Matching Concepts } & \multirow{2}{*}{17} & $\mathrm{f}$ & - & 1 & - & 3 & 5 & 3 & 5 & \multirow{2}{*}{5,41} & \multirow{2}{*}{1,37} \\
\hline & & & $\%$ & - & 5,88 & - & 17,65 & 29,41 & 17,65 & 29,41 & & \\
\hline \multirow[t]{2}{*}{4} & \multirow{2}{*}{$\begin{array}{l}\text { Matching parts of text with } \\
\text { images }\end{array}$} & \multirow{2}{*}{15} & $f$ & - & 1 & 1 & 2 & 5 & 1 & 5 & \multirow{2}{*}{5,27} & \multirow{2}{*}{1,52} \\
\hline & & & $\%$ & - & 6,67 & 6,67 & 13,33 & 33,33 & 6,67 & 33,33 & & \\
\hline \multirow[t]{2}{*}{5} & \multirow[t]{2}{*}{ Puzzle } & \multirow{2}{*}{18} & $f$ & 1 & 2 & - & 1 & 4 & 7 & 3 & \multirow{2}{*}{5,11} & \multirow{2}{*}{1,72} \\
\hline & & & $\%$ & 5,56 & 11,11 & - & 5,56 & 22,22 & 38,89 & 16,67 & & \\
\hline 6 & Finding a Title & 15 & $\mathrm{f}$ & - & 1 & 3 & 1 & 2 & 5 & 3 & 5,07 & 1,61 \\
\hline
\end{tabular}




\begin{tabular}{|c|c|c|c|c|c|c|c|c|c|c|c|c|}
\hline & & & $\%$ & - & 6,67 & 20,00 & 6,67 & 13,33 & 33,33 & 20,00 & & \\
\hline \multirow[t]{2}{*}{7} & \multirow[t]{2}{*}{ Defining Words } & \multirow{2}{*}{15} & $\mathrm{f}$ & 1 & 1 & 1 & 1 & 4 & 3 & 4 & \multirow{2}{*}{5,07} & \multirow{2}{*}{1,80} \\
\hline & & & $\%$ & 6,67 & 6,67 & 6,67 & 6,67 & 26,67 & 20,00 & 26,67 & & \\
\hline \multirow[t]{2}{*}{8} & \multirow[t]{2}{*}{ Crossword } & \multirow{2}{*}{15} & $\mathrm{f}$ & 1 & 1 & 1 & 2 & 3 & 3 & 4 & \multirow{2}{*}{5,00} & \multirow{2}{*}{1,82} \\
\hline & & & $\%$ & 6,67 & 6,67 & 6,67 & 13,33 & 20,00 & 20,00 & 26,67 & & \\
\hline \multirow[t]{2}{*}{9} & \multirow[t]{2}{*}{ Thought Balloons } & \multirow{2}{*}{15} & $\mathrm{f}$ & - & 1 & 1 & 4 & 5 & 1 & 3 & \multirow{2}{*}{4,87} & \multirow{2}{*}{1,40} \\
\hline & & & $\%$ & - & 6,67 & 6,67 & 26,67 & 33,33 & 6,67 & 20,00 & & \\
\hline \multirow[t]{2}{*}{10} & \multirow[t]{2}{*}{ Role Playing } & \multirow{2}{*}{14} & $\mathrm{f}$ & 1 & 2 & 2 & - & 1 & 6 & 2 & \multirow{2}{*}{4,71} & \multirow{2}{*}{1,97} \\
\hline & & & $\%$ & 7,14 & 14,29 & 14,29 & - & 7,14 & 42,86 & 14,29 & & \\
\hline \multirow[t]{2}{*}{11} & \multirow[t]{2}{*}{ Writing a Poem } & \multirow{2}{*}{14} & $f$ & 2 & 1 & 2 & - & 2 & 4 & 3 & \multirow{2}{*}{4,64} & \multirow{2}{*}{2,12} \\
\hline & & & $\%$ & 14,29 & 7,14 & 14,29 & - & 14,29 & 28,57 & 21,43 & & \\
\hline \multirow[t]{2}{*}{12} & \multirow[t]{2}{*}{ Analyzing the Title } & \multirow{2}{*}{18} & $f$ & 1 & 1 & 4 & 4 & 3 & - & 5 & \multirow{2}{*}{4,50} & \multirow{2}{*}{1,83} \\
\hline & & & $\%$ & 5,56 & 5,56 & 22,22 & 22,22 & 16,67 & - & 27,78 & & \\
\hline \multirow[t]{2}{*}{13} & \multirow[t]{2}{*}{ Listening (III) } & \multirow{2}{*}{15} & $\mathrm{f}$ & - & 2 & 2 & 4 & 4 & 1 & 2 & 4.40 & 140 \\
\hline & & & $\%$ & - & 13,33 & 13,33 & 26,67 & 26,67 & 6,67 & 13,33 & 4,40 & 1,49 \\
\hline 14 & Listening (II) & 20 & $f$ & 3 & 2 & 5 & 2 & 3 & - & 5 & 100 & 200 \\
\hline & & 20 & $\%$ & 15,00 & 10,00 & 25,00 & 10,00 & 15,00 & - & 25,00 & 4,00 & $2,0 Y$ \\
\hline 15 & Listening (I) & م0 & $f$ & 4 & 3 & 5 & 3 & - & 1 & 4 & 55 & 10 \\
\hline & & 20 & $\%$ & 20,00 & 15,00 & 25,00 & 15,00 & - & 5,00 & 20,00 & J,JJ & 2,10 \\
\hline
\end{tabular}

As shown in Table 3, the average values of the answers given by the students to the questionnaire are listed from top to bottom according to the highest and lowest average. Accordingly, it is seen that students show the highest participation willingness among the applied activities in "Making fairy tale characters speak (M: 5,67), "Poetry Collage" (M: 5,55), "Matching Concepts" (M: 5,41), "Puzzle" (M: 5,11) and "Finding the Title" (M: 5,07) activities where the visuals and materials are used effectively. It is understood that the lowest participation willingness among the 15 activities implemented by the students is shown in "Listening (III)" (M: 4,40), (II) (M: 4,00) and (I) (M: 3,55) activities of the German fairy tale text.

As a result, it is understood that the students showed the highest participation request among the 15 applied activities in the activity of "Making fairy-tale characters speak" with an average of M: 5.67.

\subsection{Students' Views Regarding Their Willingness to Perform Student-Centered Activities}

The themes reached when the opinions about the students' willingness to perform student-centered activities implemented within the first phase of the three-stage teaching model are analyzed are given in Table 4.

Table 4. Themes Reflecting the Opinions on the Activities of the Before Reading the Text-Stage

\begin{tabular}{lllc}
\hline \multicolumn{1}{c}{ Main themes } & \multicolumn{1}{c}{ Sub-Themes } & Opinion & $\begin{array}{c}\text { Freq. } \\
\text { (f) }\end{array}$ \\
& It is a fun activity & Positive & 13 \\
\multirow{2}{*}{ 1. Puzzle } & Images are engaging & Positive & 5 \\
& It facilitates the teaching of vocabulary & Positive & 2 \\
& It requires motor skills & Positive & 1 \\
\hline 2. Matching Concepts & It facilitates the teaching of vocabulary & Positive & 9
\end{tabular}




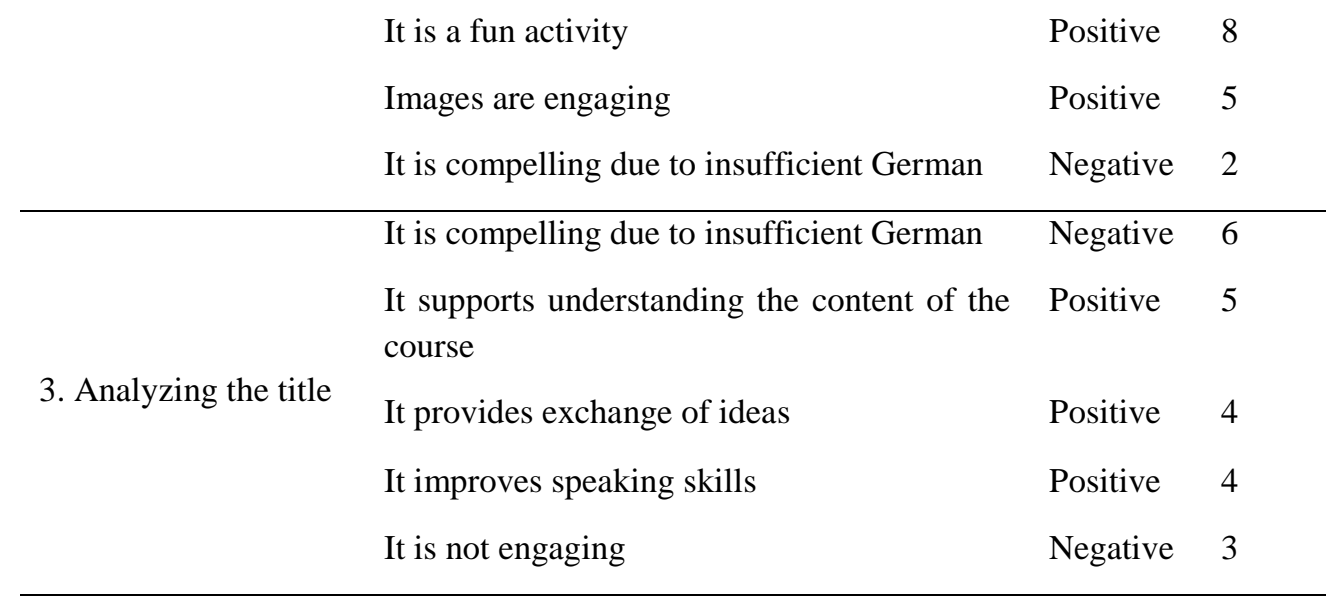

When Table 4 is analyzed, four positive sub-themes can be reached for students' willingness to realize the puzzle activity implemented within the first phase. The highest number of frequency among these sub-themes belongs to the theme that the students find puzzle activity enjoyable and express positive opinions about their willingness for participation. Student's sentences which were originally in Turkish were translated into English. An example statement showing that students' willingness for participation are positive due to the fact that the activity in question is fun is given below:

I think it is an entertaining activity that increases participation. Interactive courses motivate me more. (Student 18)

Among the positive opinions about the willingness to realize the puzzle activity, it is also understood that the students find the fairy tale visuals used in this activity interesting and useful in learning new German words:

First of all, I would like to state that the pictures are engaging and the harmony of the pictures is impressive. This will help the student be serious during an exercise. (Student 1)

Thanks to the puzzle and the visuals, everyone had fun and learned the words easily. (Student 7)

A student expresses a positive opinion since the puzzle activity is carried out with motor skills:

\section{I like to spend time doing handicrafts. (Student 8)}

When the opinions about the activity of matching the applied concepts after the completion of the puzzle activity were analyzed, three positive and one negative sub-themes were reached. It is seen that this activity, which aims to teach keywords of the text through visuals related to the subject of the text to be taught, is described as an entertaining and engaging activity that facilitates learning new words by students:

The activity of sticking the concepts to the appropriate places was the part I liked the most. It is because we are learning new words and seeing them in pictures and we can easily put them into our minds. (Student 1)

I was focused while doing it because it attracted my attention more than the other activities. (Student 4)

Some students state that they do not have sufficient knowledge of German in order to complete the concept-matching activity and therefore they have difficulty in doing this activity. It is understood that the students expressed negative opinions about their willingness to do the activity as they had difficulty in completing the activity:

It is because I didn't know all the words and I had some difficulty. (Student 16)

It was a bit difficult to focus on words. It was hard for me. (Student 9) 
Three positive and two negative sub-themes were reached when examining the opinions about the title analyzing activity applied lastly within the scope of the teaching stage before reading the text. The highest number of frequency for the activity, which aims to get the students to make predictions about the fairy tale by speaking German over the title hanging on the board, belongs to a negative sub-theme. It is understood that this activity is hard for the students in terms of language and their willingness for participation is negatively affected:

As our knowledge of German is weak, we did not attend the classes that much. (Student 17)

On the other hand, it is understood that some students have a positive opinion about their willingness to perform the title analyzing activity, and thanks to this activity, they can understand the text taught in the course, they find exchanging ideas beneficial within the scope of the activity, and they think it is positive for the development of speaking skill on the topic:

I think that making predictions about the fairy tale and then checking whether these predictions are correct according to the text help us better understand the text. (Student 18)

It generates new and different ideas and allows us to exchange ideas in a chat mood. (Student 19)

In the second stage, nine student-centered activities were implemented in order to carry out a playful and enjoyable environment within the scope of examinations to understand the text. The themes that reflect the views of these nine student-centered activities on students' willingness to participate in the course are given in Table 5 .

Table 5. Themes Reflecting the Views on the Activities of the Text Reading Stage

\begin{tabular}{|c|c|c|c|}
\hline Main themes & Sub-themes & Opinion & $\begin{array}{l}\text { Freq. } \\
\text { (f) }\end{array}$ \\
\hline \multirow{4}{*}{ 4. Listening (I) } & It is compelling due to insufficient German & Negative & 18 \\
\hline & It helps learning German & Positive & 3 \\
\hline & It uses the previously learned words & Positive & 2 \\
\hline & It is understandable by guessing & Positive & 1 \\
\hline \multirow{3}{*}{ 5. Listening (II) } & $\begin{array}{l}\text { It is better understood after listening to the } \\
\text { voice recording for the second time }\end{array}$ & Positive & 10 \\
\hline & It is compelling due to insufficient German & Negative & 6 \\
\hline & It helps learning German & Positive & 3 \\
\hline \multirow{5}{*}{ 6. Listening (III) } & $\begin{array}{l}\text { It is better understood after listening to the } \\
\text { voice recording for the third time }\end{array}$ & Positive & 6 \\
\hline & $\begin{array}{l}\text { The visual materials used support } \\
\text { understanding the text that is listened to. }\end{array}$ & Positive & 6 \\
\hline & It is compelling due to insufficient German & Negative & 2 \\
\hline & It improves word pronunciation & Positive & 1 \\
\hline & It is not engaging & Negative & 1 \\
\hline \multirow{2}{*}{$\begin{array}{l}\text { 7. Matching parts } \\
\text { of text with images }\end{array}$} & $\begin{array}{l}\text { The visual materials used support } \\
\text { understanding the text that is listened to }\end{array}$ & Positive & 6 \\
\hline & It is engaging & Positive & 5 \\
\hline
\end{tabular}




\begin{tabular}{|c|c|c|c|}
\hline & It teaches new words by guessing & Positive & 4 \\
\hline & $\begin{array}{l}\text { Prior knowledge is sufficient to complete the } \\
\text { activity }\end{array}$ & Positive & 1 \\
\hline & It is compelling due to insufficient German & Negative & 1 \\
\hline \multirow{5}{*}{ 8. Defining words } & It supports vocabulary teaching & Positive & 11 \\
\hline & It is compelling due to insufficient German & Negative & 2 \\
\hline & It is a fun activity & Positive & 1 \\
\hline & It makes the text to be read easier to understand & Positive & 1 \\
\hline & It includes a puzzle & Positive & 1 \\
\hline \multirow{3}{*}{ 9. Finding a Title } & It encourages creativity & Positive & 10 \\
\hline & It is useful for teaching words and sentences & Positive & 5 \\
\hline & It is compelling due to insufficient German & Negative & 3 \\
\hline \multirow{5}{*}{$\begin{array}{l}\text { 10. Making fairy } \\
\text { tale characters } \\
\text { speak }\end{array}$} & It is a fun activity & Positive & 8 \\
\hline & It supports the understanding of the text taught & Positive & 6 \\
\hline & It encourages creativity & Positive & 4 \\
\hline & It is compelling due to insufficient German & Negative & 3 \\
\hline & It is carried out as a pair work & Positive & 2 \\
\hline \multirow{5}{*}{$\begin{array}{l}\text { 11. Thought } \\
\text { Balloons }\end{array}$} & $\begin{array}{l}\text { The visual materials used support } \\
\text { understanding }\end{array}$ & Positive & 5 \\
\hline & It is a fun activity & Positive & 5 \\
\hline & It helps learning German & Positive & 3 \\
\hline & $\begin{array}{l}\text { Written expressions are simple and } \\
\text { understandable }\end{array}$ & Positive & 2 \\
\hline & It is compelling due to insufficient German & Negative & 1 \\
\hline \multirow{5}{*}{ 12. Crossword } & It is a fun activity & Positive & 8 \\
\hline & It supports vocabulary teaching & Positive & 6 \\
\hline & It is engaging & Positive & 3 \\
\hline & It is compelling due to insufficient German & Negative & 2 \\
\hline & It is not used frequently in courses & Positive & 1 \\
\hline
\end{tabular}

When the opinions about the willingness to perform the first listening activity applied within the second stage of the teaching application were examined, one negative and three positive sub-themes were reached. According to this, the majority of the students stated that they had a hard time understanding the recording of the fairy tale text that is to be read, and that their willingness for participation was negatively affected:

With the restlessness and anxiety of not understanding the first time I listened to the recording, I couldn't do anything and in the end, I didn't understand the recording. (Student 2)

When I first listened, I had a hard time understanding most of the words and not participating in such an activity before. So I didn't want to join. (Student 11) 
Although there are primarily negative opinions about the first listening activity of the voice recording, some of the students also appear to have reported positive opinions about the activity in question. According to this, some students state that they find this activity generally useful and thanks to this activity they can better understand the meaning of the words they have learned before. In addition, it is seen that a student expresses a positive opinion since this activity can be resolved by making predictions. Below are some exemplary statements containing positive views on the first listening activity:

It was useful to learn by hearing the words I saw. (Student 19)

Listening increased my interest in the course. It was useful even if I had trouble understanding. (Student 7)

I think that listening to the beginning of a text and analyzing it helps us to understand the text better. (Student 18)

When the opinions on the effectiveness of playing the recording for the second time are analyzed, two positive and one negative sub-themes are seen. First of all, it is seen that students understand the second listening activity better than the first listening activity and therefore they stated that their willingness to participate in the course increased:

When I listened a second time, I was able to perceive the words better. This increased my willingness to participate. (Student 8)

In the second listening activity, as in the first listening activity, it is seen that some students have difficulty in understanding the recording and give negative opinions about their willingness to participate in the course:

I had difficulty in being interested in the course because I could not fully understand the text. So I lost interest in the activity. (Student 1)

Apart from this, it is observed that a few students think that the second listening activity is beneficial and express positive opinions:

It helped me not only listen but also learn while listening. (Student 13)

When the views on the third listening activity are examined, three positive and two negative subthemes are seen. It is understood that during the third listening activity, students do not have much difficulty compared to the first and second listening activities and they understand the listening text better through the visual materials used in the activity. Sample expressions reflecting the students' views on these positive themes are presented below:

I understood because we listened for the third time and I felt that I was not having difficulty doing it. (Student 2)

I listened to the fairy tale for the third time, and as the pictures helped me follow the fairy tale, my participation willingness increased because I did the activity easily. (Student 14)

When the negative student views on the third listening activity of the recording are analyzed, it is understood that some students have difficulty in doing the activity and do not find it engaging and thus their willingness for participation is also negative:

I had trouble understanding the course of the tale because I didn't know the words. (Student 5)

It did not attract my attention in terms of participation. (Student 9)

Apart from this, it is seen that some students think that the activity in question improves word pronunciation and they have a positive opinion about doing the activity:

Because listening helped me to pronounce words as it makes the words recognizable. (Student 8) 
After completing the listening activities, four positive and one negative sub-themes were reached when the views on the activity of matching the parts of the text with the pictures were examined. In this context, it is stated that the visual materials used primarily in the scope of this activity support the learning and therefore they have a positive effect on their willingness to do the activity:

When I see them visually, the words are easier to remember. (Student 1)

Linking German words with pictures made it easier for me to learn the word meanings. (Student 8)

It is also understood that the students find this activity enjoyable and the fact that it is carried out by using their prediction and prior knowledge positively affects their desire to perform the activity. Expressions about these positive sub-themes of the students are given below:

It was quite enjoyable to do activities with pictures. It is easier to remember with pictures. (Student 15)

It allowed me to better understand the texts I read because it helps me learn by guessing a sentence I don't understand or a word I don't know the meaning of. (Student 11)

Thanks to this activity, we learned how much we understand what we read. Even knowing a few words helped match parts of text with pictures. (Student 7)

It seems that a student found it difficult to match the text parts with the pictures, and therefore the willingness for participation was negatively affected:

I was less willing to participate because this activity was a little difficult for me. (Student 13)

When the students' opinions about word definition activity were examined, four positive and one negative sub-themes were identified. Accordingly, the students state that they found the activity in question useful in terms of vocabulary teaching and therefore they wanted to perform the activity:

Instead of being given the meaning of a word in Turkish, trying to find out the definition of that word allows me to learn the meaning of that word better. (Student 11)

When other positive opinions are examined, it is seen that the students find this activity enjoyable and the fact that it is carried out in the form of puzzles makes it easier to understand the text to be read, and that is why their participation willingness increased:

As I learned the meaning of the words, I wanted to participate because I understood the texts. (Student 1)

It was fun and useful to translate the explanations of new words with learned meanings from German into Turkish. (Student 7)

It was nice to learn new words. This activity was a bit like a puzzle, so I liked it. (Student 13)

The only negative sub-theme for this activity is that the activity in question is challenging some students in terms of language:

I couldn't understand the words and the explanations. This made it very difficult. (Student 5)

Two positive and one negative sub-themes were reached when the views on the title finding activity were examined. The students state that they worked creatively while performing this activity and found the activity useful for the teaching of words and sentences. Some statements containing the positive opinions expressed in this context are given below:

While I find a title describing the pictures, I can make fun and creative things. I tried to make a fun and compatible title. (Student 14)

It was an activity that taught us how to form a sentence. (Student 4) 
The activity reinforced the words we learned the meaning of. (Student 3)

Apart from that, it is seen that the activity of finding a title challenged some students in terms of language and lead to negative opinions about their willingness for participation:

It was a little difficult to find a title because I know almost no words in German. But we completed the activity with the help of teachers. (Student 1)

When the opinions about the effectiveness of the activity of making fairy tale characters speak after the title finding activity were examined, four positive and one negative sub-themes were found. When the positive sub-themes are examined, it is understood that the students consider the title finding activity as a fun activity and they think that they better understand the text taught in the course thanks to this activity. In addition, expressions about the creativity and working as groups of pairs are among the positive opinions of the students. Some expressions used by students in this context are given below:

My desire to participate was more in this event since reading and matching the characters' thoughts was very instructive and fun in terms of completing the story. (Student 14)

The dialogues we wrote using our imagination enabled us to compare with different sentences compared to the classical memorization method. (Student 6)

I had so much fun doing it with my friend. (Student 5)

However, several students explain that their knowledge of German is insufficient in writing dialogue for fairy-tale characters, and that is why their willingness to perform the activity is negatively affected:

Since my grammar knowledge in German was not sufficient, I did not participate in the activity much. (Student 14)

When the opinions about the willingness to do the thought balloons activity were examined, four positive and one negative sub-themes were reached. First of all, students state that the visual materials used in the activity of thought balloons were qualified to support learning German in general. Apart from this positive view, the students state that they find this activity enjoyable and that the expressions used in the balloons were easily understood by them, which positively affects their willingness to participate in the event. In this context, some expressions about the positive opinions of the students about doing the activity are given below:

Visuality made sentences easier to remember. (Student 6)

I think it's useful to understand what's written and find out who says it because it makes me pay attention to pronouns and personal affixes. In this way, it allows me to learn what to use where and for whom. (Student 11)

I made it easily because the sentences in thought balloons are similar to our sentences. (Student 2)

The only negative sub-theme reached in the examination of the opinions on the thought balloons activity is that the activity in question was hard for a student in terms of language:

This activity was difficult for me and I did not want to participate. (Student 13)

Within the scope of the second stage of the three-stage teaching model, when the opinions about the crossword puzzle activity were examined, four positive and one negative sub-themes were reached. When the positive opinions about performing the puzzle activity are examined, it is seen that the students find this activity enjoyable, interesting and useful in developing the German vocabulary. It is also understood that the puzzle activity is an unusual activity within the scope of high school courses, which increases the student's willingness to perform the activity. Some expressions about the students' willingness to do the puzzle activity are given below:

I had fun doing this because I like solving puzzles. I think I learned words better. (Student 13) 
Finding the words with the help of the text and placing them correctly was mind-opening and entertaining. I participated and I think I was successful. (Student 3)

Solving puzzles helped me to get my attention and focus. (Student 10)

\section{I like it because it's a different activity. (Student 7)}

At the same time, some students state that their willingness to perform puzzle activities is negative due to the insufficient knowledge of German:

I am afraid to participate in the activity because my knowledge of German is not enough. (Student 8)

Within the scope of the third phase of the teaching model applied, three student-centered activities were implemented in order to enable students to create creative writing styles from the fairy tale text discussed in the course. The themes reflecting the opinions of these three activities about the participation in the course are given in Table 6.

Table 6. Themes Reflecting the Opinions on the Activities of After Reading the Text Stage

\begin{tabular}{llll}
\hline Main themes & \multicolumn{1}{c}{ Sub-themes } & Opinion & $\begin{array}{c}\text { Freq. } \\
\text { (f) }\end{array}$ \\
\hline \multirow{3}{*}{ 13. Role Playing } & It is a fun activity & Positive & 6 \\
& It supports German speaking skills & Positive & 4 \\
& It encourages creativity & Positive & 3 \\
& It is compelling due to insufficient German & Negative & 2 \\
& Our mistakes are ignored & Positive & 1 \\
& Role cards are used & Positive & 1 \\
& It is a childlike activity & Negative & 1 \\
& It is an activity that was tried for the first time & Positive & 1 \\
\hline \multirow{3}{*}{ 14. Writing a Poem } & It is compelling due to insufficient German & Negative & 8 \\
& It increases self-confidence & Positive & 4 \\
& It incrivity & Positive & 1 \\
\hline & It is a fun activity & Positive & 9 \\
& It encourages creativity & Positive & 7 \\
It facilitates the teaching of vocabulary & Positive & 4 \\
& Motor skills are required & Positive & 2 \\
& It is a childlike activity & Negative & 2
\end{tabular}

Six positive and two negative sub-themes were identified as a result of the analysis of the opinions of the role play activity implemented within the scope of the third phase regarding the students' participation willingness. When the positive opinions about the desires to realize the activity are examined, it is seen that the students find the activity in question primarily as entertaining, beneficial for the development of German speaking skills and encouraging for creative work. Example views on these themes are presented below: 
This was the most fun event of the day. Because we played improvisationally. Masks, on the other hand, added a different atmosphere to the activity. (Student 12)

It was fun for us to create a script and play it. I think it improves my speaking skills because we improvise. Masks made it even more fun. (Student 13)

Apart from this, some students state that the speech mistakes they make within the scope of the role play activity are not corrected and that the role play is carried out with pre-prepared role cards positively affects their participation willingness:

It was a fun activity. We played and tried to talk, regardless of how we formed sentences. (Student 10)

The use of role cards was good for class participation. (Student 4)

Another student says that s/he participated in a role play event for the first time and that they were not very successful as a group, but that her willingness to participate was positively affected:

Role playing was an original idea. I've never done this before. I had a desire to participate, but our first attempt was not very successful. (Student 2)

When the negative opinions about the willingness to do the activity are analyzed, it is understood that some students have difficulties in terms of language and wearing masks during the role play activity. Some statements about these two negative sub-themes are given below as an example:

We don't have the ability to establish a dialogue, so we had a hard time when we were asked to create a dialogue. (Student 8)

I don't like wearing a mask. I think we passed that age. (Student 1)

When the opinions about the poetry writing activity applied after the role play activity were examined, two positive and one negative sub-themes were reached. First of all, it is seen that the activity of poetry writing in these themes challenges students in terms of language and therefore their views on doing the activity are negative:

I did not enjoy this activity because having hard time in some places reduced my willingness to participate. (Student 15)

However, some students state that it is difficult to write poetry but they still find this activity enjoyable and their self-confidence increases when they complete the activity:

Writing the poem in German was difficult, but it helped to translate it into Turkish and translate it with a dictionary. It was entertaining and instructive. (Student 2)

It was a creative activity and being able to create sentences increased my self-confidence. (Student 1)

Finally, when the student views on the poetry collage activity are examined, four positive and one negative sub-themes were reached. When the positive opinions about the willingness to make a collage of poetry are examined, it is seen that the students find the activity in question primarily entertaining, encouraging for creative work and beneficial in learning German words. Example expressions related to these sub-themes can be seen below:

That was so fun. While cutting with scissors, I was able to find the words directly from the other texts because I had memorized the spelling of the words. (Student 3)

I enjoyed it because the collage was a creative activity. (Student 7)

I think it's a good activity. In this way, I can learn German words more quickly and do good work using our imagination. (Student 8) 
When the negative opinions about the willingness to perform the poetry collage activity are examined, it is stated that some students find this activity childish and therefore their participation willingness is negatively affected:

Frankly, I didn't want to participate because this activity was bit childish. (Student 6)

\subsection{Students' recommendations for German Courses with Student-centered Activities:}

Through the course evaluation forms applied in the study, the students made suggestions for German course practices carried out in general with student-centered activities. Students' suggestions for studentcentered German courses at high school level are presented in Table 7:

Table 7. Students' recommendations for course practices

\begin{tabular}{llc}
\hline & $\begin{array}{l}\text { Continuation of classes with student-centered } \\
\text { activities }\end{array}$ & 14 \\
& Use of Turkish translations & 4 \\
& Use of more visual materials & 4 \\
Recommendations for course & Courses conducted in a simpler German & 3 \\
practices: & Competition-style activities & 3 \\
& Use of simpler voice recordings & 1 \\
& $\begin{array}{l}\text { Informing teachers of other branches about the } \\
\text { benefits of student-centered activities }\end{array}$ & 1 \\
\end{tabular}

According to the recommendations of the research for the course practices reflected in Table 7, it is seen that the students find it helpful to integrate the German courses with student-centered activities and they recommend that German courses be continued with these types of activities. Some of the recommendations that students state in this context are as follows:

Keep up the good work. It is really useful. The words were engraved in my memory even though I didn't repeat them at home. (Student 1)

Such fun and encouraging things should continue to be done. (Student 13)

I think my German will improve if it continues like this. (Student 12)

Some expressions are given below, emphasizing the need to include Turkish translations more frequently in such practices carried out in German courses, and that teachers should use voice recordings in a simpler and more understandable way:

I recommend speaking Turkish rather than speaking German all the time. (Student 2)

I suggest it to be explained at a lower level because the overall level of the class is not very high. (Student 3)

The voice recording could have been at a lower level because I didn't understand most words. (Student 10)

In addition, some students recommend using visual materials in German courses and recommend increasing the use of such materials:

It should continue to be taught visually because I think it's more effective and permanent. (Student 18) 
Some students also recommend that student-centered activities be carried out in the form of a competition:

We could do our activities in the form of an awarded competition such as choosing the most beautiful poem. (Student 12)

A student suggests that other teachers should also be informed about the benefits of such studentcentered course practices.:

Our teachers should be informed about the benefits of this course and they should also benefit from these methods. (Student 14)

\section{Discussion}

In this study, the findings obtained from two different data collection tools shed light on the reasons why the student-centered activities of the student-centered teaching practices in German courses at high school level are desired by the students. In this context, it is seen that the findings obtained from the questionnaire and course evaluation forms support each other. Therefore, when the findings obtained from the quantitative data analysis for the first research question "What is the willingness of the students to perform student-centered activities applied in German courses?" are examined, it is seen that the students especially want to participate in the activities where the visual materials are used and the creative work style is required. Accordingly, "Making fairy tale characters speak", "Poetry Collage", "Matching Concepts", "Matching parts of text with images" and "Puzzle," where various fairy tale visuals are used and which require creative thinking skills, are the activities in which the willingness to participate is highest. On the other hand, it is observed that the students' willingness to participate has decreased in activities which are carried out only through texts and voice recordings, such as "Writing a Poem" or "Listening".

When the findings obtained from the qualitative data analysis related to the second research question "What are the views of the students regarding their willingness for participation in student-centered activities implemented in German courses?" are examined, it is seen that the students primarily give positive opinions about the majority of the activities implemented. According to the opinions of the students, most of the activities implemented are fun, interesting and positively affect the German learning processes. However, it is seen that some students find themselves insufficient in terms of language and therefore consider the activities as challenging and boring even though these views are less than the positive ones. As a result, the assumption that student-centered activities contribute to the increase in the willingness to participate in courses is confirmed.

When the findings related to the opinions of the students about the teaching of German lessons through student-centered activities are examined, it is understood that the students recommend that foreign language lessons be continued primarily through student-centered teaching practices and student-centered activities. Based on the opinions expressed in this context, it has been determined that students use only positive and advisory expressions for the education method applied. Their opinions are generally aimed at improving and expanding these student-centered education practices.

\section{Conclusion}

Making students active in a foreign language course is an absolute necessity of a foreign language course because it is a known fact that students who are active in the course develop their foreign language skills much faster than those who stay passive (Ünal, 2005, p. 208). This study, which is 
designed based on the principles of student-centered education method, shows how to increase the participation willingness of students at high school level in a meaningful and positive way. It is a known fact that high school students are preparing for the university entrance exam due to their ages and educational levels, thus they are mostly educated in teacher-centered course settings. In this sense, there is a need for student-centered foreign language learning environments in which high school students can become active and learn while having fun so that they do not have a negative attitude towards the foreign language (Schröder, 2007, p. 212; Portman-Tselikas, 2010, p. 1168). This assumption does not mean that foreign language education should be simplified more or the expectations of educators should be lowered. Accordingly, well-structured learning environments according to the principles of studentcentered education approach through student-centered activities will positively affect students' success, interest and attitude in foreign language lessons (Dockhorn, 2008, p. 51). Therefore, it can be argued that focusing primarily on student-centered activities and students' participation in the learning process is a correct approach in order to ensure that high school students achieve the goals of their current foreign language education.

\section{Ethics Committee Approval}

The author confirms that ethical approval was obtained via Akademi Lise İşbirliği Protokolü (Approval Date: 03/02/2020).

\section{References}

Açıkgöz, K. Ü. (2003). Aktif öğrenme. İzmir: Eğitim Dünyası Yayınları.

Aypay, A., \& Eryılmaz, A. (2011). Lise Öğrencilerinin Derse Katılmaya Motive Olmaları ile Okul Tükenmişliği Arasındaki İlişkinin İncelenmesi. Mehmet Akif Ersoy Üniversitesi Eğitim Fakültesi Dergisi, 11(21), 26-44.

Baş, T. (2005). Anket nasıl hazırlanır, uygulanır, değerlendirilir?. Ankara: Seçkin.

Burwitz-Melzer, E., \& Steiniger, I. (2016). Inhaltsanalyse. In D. Caspari, F. Klippel, M. K. Legutke, \& K. Schramm (Eds.), Forschungsmethoden in der Fremdsprachendidaktik - Ein Handbuch (pp. 256268). Tübingen: Narr Francke Attempto Verlag.

Can, E. , Can, C. I. (2014). Türkiye'de İkinci Yabancı Dil Öğretiminde Karşılaşılan Sorunlar. Trakya Üniversitesi Eğitim Fakültesi Dergisi, 4(2), 43-63.

Caspari, D. (1997). Übersicht über kreative Umgangsformen mit literarischen Texten. Der fremdsprachliche Unterricht Englisch, 31(3).44-45.

Çanlıŏlu, Ş. (2014). Illetişimsel Yöntem Aktiviteleri Kullanarak İngilizce Öğrenen Öğrencilerin Derse Katılım Düzeyini Artırma Vaka Çalışması (Unpublished master's thesis). Çağ Üniversitesi, Mersin.

Demirpolat, B. Ç. (2015). Türkiye'nin Yabancı Dil Öğretimiyle İmtihanı - Sorunlar ve Çözüm Önerileri. Ankara: SETA.

Dockhorn, B. (2008). Lernerzentrierte und aktivierende Lehre - Konzeption und Umsetzung am Beispiel des teilvirtuellen Seminars »Multimediale Landeskunde». Tübingen: Eberhard Karls Universität Tübingen.

Duman, G., \& Eren, A. (2014). Öğretmen Adaylarının Başarı Amaçları, Öğrenme Stratejileri Ve Derslere Katılımları: Bir Arabuluculuk Analizi. K. Ü. Kastamonu Ĕgitim Dergisi, 23(3), 1074-1064. 
Ehlers, S. (2010). Literarische Texte im Deutsch als Fremd- und Zweitsprache -Unterricht: Gegenstände und Ansätze. In H. J. Krumm, C. Fandrych, B. Hufeisen, \& C. Riemer (Eds.), Deutsch als Fremdund Zweitsprache - Ein internationales Handbuch (pp. 1530-1544). Berlin: De Gruyter Mouton.

Fink, L. D. (2003). Leitfaden zur Konzeption und Planung von Lehrveranstaltungen, die nachhaltiges Lernen fördern. Retrieved on January 15, 2020, from https://www.deefinkandassociates.com/German_SelfDirectedGuide.pdf

Gardner, R. C. (1985). Social Psychology and Second Language Acquisition. The Role of Attitudes and Motivation. London: Arnold.

Güçlü, M., Şahan, A. (2019). Türkiye Süreli Yayınlara Yansıyan Yabancı Dil Eğitim Konulu Araştırmalar (2014-2019). The Journal of International Social Research, 12(66), 802-812. DOI: $10.17719 /$ jisr.2019.3629

Güler, A., Halıcıoğlu, M. B., \& Taşğın, S. (2015). Sosyal Bilimlerde Nitel Araştırma. Ankara: Seçkin.

Hofmann, H. (2004). Literarische Texte als Sprech- und Schreibanlass. In H. Stoyan \& E. Vincze (Eds.), Kinderliteratur im Fremdsprachenunterricht (pp. 117-124). Budapest: Trezor Kiadó.

Işık, A. (2008). Yabancı Dil Eğitimimizdeki Yanlışlar Nereden Kaynaklanıyor?. Journal of Language and Linguistic Studies, 4(2), 15-26.

İnci, T. (2019). Bağlam Temelli Öğrenme Ortamı Algısl, Derse İlgi, Derse Katilim Ve Akademik Güdülenme Etkileşiminin Ortaokul Öğrencilerinin Fen Bilimleri Başarısına Etkisi (Unpublished doctoral dissertation). Eskişehir Osmangazi Üniversitesi, Eskişehir.

İşigüzel, B., Kırmızı, B. (2014). Lise Öğrencilerinin Almanca Öğrenme Sürecinde Başarısızlık Nedenlerinin Değerlendirilmesi. Kafkas Üniversitesi Sosyal Bilimler Enstitüsü Dergisi, 13, 45-63. DOI: $10.9775 /$ kausbed.2014.004

Kast, B. (1994). Literatur im Anfängerunterricht. Fremdsprache Deutsch, 11, 4- 13.

Kırmızı, B. (2009). Anadolu Liselerindeki Almanca Dersinde Yer Alan Dilbilgisi Konularının Öğretiminde Karşılaşılan Sorunlar. Pamukkale Üniversitesi Eğitim Fakültesi Dergisi, 26, $42-53$.

Knorr, P., \& Schramm, K. (2016). Triangulation. In D. Caspari, F. Klippel, M. K. Legutke, \& K. Schramm (Eds.), Forschungsmethoden in der Fremdsprachendidaktik - Ein Handbuch (pp. 90-97). Tübingen: Narr Francke Attempto Verlag.

Krauß, C. (2004). Attraktivität durch Multifunktionalität - Der literarische Text im Fremdsprachenunterricht DaF. In H. Stoyan \& E. Vincze (Eds.), Kinderliteratur im Fremdsprachenunterricht (pp. 45-52). Budapest: Trezor Kiadó.

Küçüktepe, C., Eminoğlu Küçüktepe, S. \& Baykın, Y. (2014). İkinci Sınıf İngilizce Dersi Ve Programına İlişkin Öğretmen Görüşlerinin İncelenmesi. Hasan Ali Yücel Eğitim Fakültesi Dergisi, 11(22), 55-78.

Milli Eğitim Bakanlığı (2018). 2023 Eğitim Vizyonu. Retrieved on December 6, 2019, from http://2023vizyonu.meb.gov.tr/doc/2023_EGITIM_VIZYONU.pdf

Nünning, A. \& Surkamp, C. (2006). Englische Literatur unterrichten. Seelze-Velber: Kallmeyer.

Özpalat, V. (2013). Öğretmenlerin Mesleki Önceliklerinde Öğrenci Merkezli Eğitim Yaklaşımının Yeri. Eğitim ve Sosyal Bilimler Dergisi, 42(200), 5-27. 
Portmann-Tselikas, P. (2010). Aufgabenorientierung. In H. J. Krumm, C. Fandrych, B. Hufeisen, \& C. Riemer (Eds.), Deutsch als Fremd- und Zweitsprache - Ein internationales Handbuch (pp. 11661171). Berlin: De Gruyter Mouton.

Reeve, J., \& Tseng, C.-M. (2011). Agency as fourth aspect of students' engagement during learning activities. Contemporary Educational Psychology, 36(4), 257-267. DOI: 10.1016/j.cedpsych.2011.05.002

Reschly, A., \& Christenson, S. L. (2006). Research leading to a predictive model of dropout and completion among students with mild disabilities and the role of student engagement. Remedial and Special Education, 27, 276 - 292. DOI: 10.1177/07419325060270050301

Riemer, C. (2010). Motivierung. In H. J. Krumm, C. Fandrych, B. Hufeisen, \& C. Riemer (Eds.), Deutsch als Fremd- und Zweitsprache - Ein internationales Handbuch (pp. 1152-1156). Berlin: De Gruyter Mouton.

Schmidt, R. (2003). Schülerbeteiligung im Fach Geschichte (Unpublished doctoral dissertation). Martin-Luther Universität, Wittenberg.

Schröder, K. (2007) Fremdsprachenunterricht im Sekundarbereich II. In K. R. Bausch, H. Christ, \& H. J. Krumm (Eds.), Handbuch Fremdsprachenunterricht (pp. 208-214). Tübingen: Narr Francke Attempto Verlag.

Türk, M. (2012). Harmanlanmış Öğrenme Ortamının Meslek Yüksekokulu Öğrencilerinin Derse Katılımlarına ve Akademik Başarılarına Etkisi (Unpublished master's thesis). Gazi Üniversitesi, Ankara.

Ünal, D. Ç. (2005). Yabancı Dil Öğretiminde Edebi Metinler: Yenilikçi Yaklaşımlara Geçiş Süreci ve Gerekçeleri. Hacettepe Üniversitesi Ë̆itim Fakültesi Dergisi, 29, 203-212.

Ünal, D. Ç. (2010). Die Arbeit mit Literatur im Fach Deutsch als Fremdsprache - Neue Ansätze mit Unterrichtsentwürfen. Ankara: Hacettepe Üniversitesi Yayınları.

Ünal, D. Ç. (2018). Yüksek Edebiyattan Yığın Edebiyatına - Alman Dili Eğitimi Ana Bilim Dallarında Edebi Metin Seçimi ve Kanonlaşma Üzerine Bir İnceleme. In A. O. Öztürk, D. Ç. Ünal, \& Ü. Kaya (Eds.), Hiciv- Yı̆̆ın -Göçmen Edebiyatı Uzmanı Prof. Dr. Yüksel Baypınar Armă̆ını (pp. 53-80). İstanbul: Hiperyayın.

Üstün, E. (2016). Yabancı Dil Olarak Almanca Öğrencilerinin Özgün Ders Araç Gereçlerini Nasıl Bulduklarına Dair 10. Sinıf Örneği İle Uygulamalı Bir Çalışma (Unpublished master's thesis). Gazi Üniversitesi, Ankara.

Wicke, R. E. (2014). Werkzeuge zur Arbeit mit literarischen Texten. München: Hueber Verlag.

Wicke, R. E. (2017). So gelingts. 20 lernerzentrierte, handlungs- und produktorientierte Prinzipien des DaF/DaZ-Unterrichts. München: Hueber Verlag.

Yıldırım, A. \& Şimşek, H. (2005). Sosyal Bilimlerde Nitel Araştırma Yöntemleri. Ankara: Şeçkin.

Yılmaz, Ö., \& Dilidüzgün, Ş. (2019). Yabancı Dil Olarak Türkçe Öğretiminde Metin Odaklı Dilbilgisi Öğretimi Üzerine Öğrenci Görüşleri. Ana Dili Eğitimi Dergisi, 7(1), 217-234. 


\section{Almanca öğretiminde masallar: Öğrenci merkezli etkinliklerin öğrencilerin derse katılım isteği açısından incelenmesi}

\section{$\ddot{O} z$}

$\mathrm{Bu}$ araştırmanın amacı, ikinci yabancı dil olarak Almanca öğrenen lise öğrencilerinin dört hafta süren bir öğrenci merkezli öğretim uygulaması kapsamında yürütülen öğrenci merkezli etkinliklere yönelik katılım isteklerini ve görüşlerini belirlemektir. Araştırmanın örneklemi 2019-2020 öğretim yılının bahar döneminde Ankara-Çankaya ilçesinde bulunan bir ortaöğretim okulunun 11. sınıf öğrenime devam eden 20 öğrenciden oluşmaktadır. Araştırma karma araştırma yöntemi ile yürütülmüştür. Veri toplama araçları olarak, öğrenci merkezli etkinliklerin öğrencilerin aktif ders katılım istekleri üzerindeki etkiyi saptamak amaciyla bir anket ve öğrencilerin uygulanan etkinliklere yönelik düşüncelerini ve görüşlerini belirlemek amacıyla bir ders değerlendirme formu uygulanmıştır. Anket ve ders değerlendirme formlarından elde edilen nicel verilerin analizinde betimsel istatistik, nitel verilerinin çözümlenmesinde ise tümevarımcı içerik analiz kullanılmıştır. Değerlendirme sonucunda öğrenci merkezli öğretim uygulamaları kapsamında özellikle görsel malzemelerin ve yaratıcı çalışma biçimlerinin kullandığı öğrenci merkezli etkinliklerin öğrencilerin derse katılım isteğinin artmasında katkı sağladığı saptanmıştır. Ayrıca öğrencilerin bu tip etkinliklerin yabancı dil öğrenme süreçleri için etkili ve faydalı buldukları görüşünü paylaştıkları.

Anahtar sözcükler: yabancı dil öğretimi; yabancı dil olarak Almanca; öğrenci merkezli öğretim; öğrenci merkezli etkinlikler; derse aktif katılım

\section{AUTHOR BIODATA}

Nurcihan Sönmez Genç graduated from Hacettepe University, Department of Foreign Languages Education (German Language Education) in 2015. She is currently working as a research assistant at Hacettepe University German Language Teaching Department and is also a PhD student at Hacettepe University German Language Education Program. Her research interests are German education, teacher training and learning strategies training. 